\title{
First Conservatoire in the Urals: From the History of Russian Musical Education
}

\author{
Marina Gorodilova \\ Urals Mussorgsky State Conservatoire \\ Yekaterinburg, Russia \\ gorodilova_m_v@mail.ru \\ Elena Polotskaya \\ Urals Mussorgsky State Conservatoire \\ Yekaterinburg, Russia \\ eepol@mail.ru
}

\author{
Alla Korobova \\ Urals Mussorgsky State Conservatoire \\ Yekaterinburg, Russia \\ kor.all@list.ru \\ Lyudmila Shabalina \\ Urals Mussorgsky State Conservatoire \\ Yekaterinburg, Russia \\ lyudmila@convex.ru
}

\begin{abstract}
This article is devoted to the development of the first higher education musical institution in the Ural-Siberian region, the Ural State Conservatoire, named after Modest $P$. Mussorgsky. Within the framework of that institution's history, the main steps of its establishment are described, as well as the significance of its widespread and various activities (pedagogical, concert, scientific, and research) for the culture of the region and the country as a whole.
\end{abstract}

Keywords-Ural Conservatoire; Ural musical culture; professional musical education; cultural values

\section{INTRODUCTION}

The Ural Conservatoire in Yekaterinburg is the oldest musical establishment in the Urals and Siberia. It is the creative and methodological center for a vast area, preparing highly professional musicians (performers, teachers of all sorts, composers, researchers, and methodologists), and successfully working in different areas of musical culture. It also carries out intensive scientific-research and concertcreative activities. The year 2014 marked 80 years since the Conservatoire's founding and 175 years since the birth of M.P. Mussorgsky, whose name the Ural Conservatoire exclusively bears. This article is devoted to the milestones in its history.

\section{BEGINNING}

Founded in 1934, the Ural Conservatoire was the first musical institution in post-revolutionary Russia and, until the 1950s, the only one in the USSR east of the Volga district.

The most difficult, vivid, and, in many respects, dramatic pages of the Ural Conservatoire's history fall during its first 20 years. They coincided with the repressions of 1930s, the Great Patriotic War, and the year 1948, which is one of the most memorable in the history of Soviet music.

The choice of city for the new conservatoire was determined by Yekaterinburg's status, as it had been transformed from a small town into the capital of the Ural
Mountains (and renamed Sverdlovsk since 1924). Additionally, Yekaterinburg already possessed a musical college, set up in 1916 and based on the Russian Imperial Musical Society classes [1]. The idea of the conservatoire's foundation in the city had been announced in the local media in the early 1920s. (There were even deadlines - for example, 1st May 1920). This idea was not unreasonable. In the late autumn of 1919, a year which was extremely hard for the country, by the initiative of A.V. Lunacharsky, People's Commissar for Education, (who was aware of the needs of the local Opera House), some musicians from Petrograd were invited to Yekaterinburg. Suffering from starvation, about 130 professionals left that city. (Actually, it saved the life of many of them.) They joined the opera chorus and orchestra, and also started to teach in the musical college. It is hardly necessary to explain how this boosted the development of the Ural musical culture.

Organization of the Conservatoire on the geographical border of Europe and Asia had an ideological meaning as well. This institution was looked upon as the flagship of higher musical education of the Urals and Siberia. One of the most beautiful and significant buildings in the city center an architectural monument of the 1730s and the first stone house in the city - was allocated to it. In the Eighteenth and Nineteenth Centuries, this building was an important institution in the metallurgical district, being the main headquarters of all metallurgical factories in the Urals. After one century of use, this building, first built in the Dutch style, was augmented by the addition of a third floor, a project of M.P. Malakhov, and thus it gained a classical-style picturesque appearance, which is still visible. In 1967, the Conservatoire annexed what came to be called the Big Concert Hall - in addition to the Concert Hall (now called the Little Hall and named after S.S. Prokofiev) in a historical part of the building. Prokofiev performed there in the spring of 1935 and afterwards presented his photo, upon which it was written, "To a promising baby - Sverdlovsk Conservatoire". 
The Conservatoire's opening was authorized by an Act of Presidium of Sverdlovsk Regional Committee (№ 1135, dated 3rd September 1934) about opening of a state conservatoire in Sverdlovsk and the beginning of lessons from the 1st October [2]. But the premises, intended for the conservatoire had been occupied by managing offices of the manufacturing industry. Their dispossession turned out to be a difficult process, thus entrance exams were postponed. The problem was solved by the wind instruments players: They started to prepare for the exams in the hall immediately in front of the civil servants' offices! The building was soon cleared, and it began a new page in its history - a musical one.

From the origins of the Conservatoire, there were outstanding musicians. European roots of the Ural institution go back to the Russian pre-revolutionary musical schools, and its staff was constituted of representatives of St. Petersburg, Moscow, Kiev, Odessa, Tbilisi, and Moscow musical-drama and Sinod colleges as well as the Court Singing A Capella. The Moscow Conservatoire took a special pleasure in being a patron of the young institution and provided its teaching staff. The galaxy of brilliant names for the distant region was striking. All those musicians became the founders of the performing and creative schools, having been honored by the Conservatoire.

Among the founders and first teachers, there were composers M.P. Frolov (the first rector) and V.N. Trambitsky, pianists B.S. Maranz, S.S. Benditsky, and B.I. Pevzner, vocalists E.E. Yegorov, M.M. Umestnov, V.G. Ukhov, and A.V. Novikov, conductors A.E. Margulyan and M.I. Paverman, violinist M.I. Lidsky, cellist M.B. Petrushansky, wind instrument players and composers N.R. Bakaleinikov and V.I. Shchyolokov and others.

In that first year, there was admissions to the piano, orchestra (string and wind instruments), and vocal departments. Order № 12, dated 29th October 1934, has been preserved. It states, "Professors of Moscow State Conservatoire Nejgauz G.G. (piano) and Turovskaya V.F. (solo singing) that arrived in Sverdlovsk 25th October 1934 are to be considered participants of the admissions board for examining candidates for the first year of studies in Sverdlovsk State Conservatoire (SSC). Director of SSC M.P. Frolov" [3], [4]. In 1935, the departments of composition and musical education were added. (In 1935, the departments of theory, history of music, and composition were established.) In 1936, history-theoretical specialty was added. In 1939, on the basis of opera classes, the department of opera training was formed. In 1943, the department of choir conducting appeared. That year also saw the organizing of the a capella choir at the Sverdlovsk Philarmonic Society and the Ural Folk Choir. The newest department is that of Musical Audio Engineering Directing which was formed in 1993.

The first graduation took place in the year of the 100th anniversary of M.P. Mussorgsky's birth. The Presidium of the Supreme Soviet of the RSFSR passed a decree in June 1939 in order to celebrate this date. It said, "Henceforth Sverdlovsk State Conservatoire is to be named after composer M.P. Mussorgsky" [5]. The best of those graduates became teachers. Among them there was B.D. Gibalin, a composer who later became one of the rectors.

\section{WAR YEARS}

War years brought tremendous difficulties, but, at the same time, gathered at the Conservatoire many outstanding musicians. Due to the partial evacuation of the Moscow and Leningrad conservatoires and wholly from the Kiev conservatoire, the Kiev director, pianist A.M. Lufer, took charge of a united institution. Sverdlovsk now saw such teachers as composers P.M. Glier, V.Y. Shebalin, D.B. Kabalevsky, A.V. Bogatyrev, V.A. Bely, and B.S. Shekhter, conductors A.B. Khessin and N.S. Rabinovich, pianists G.G. Nejgauz, N.I. Golubovskaya, M.I. Grinberg, G.M. Kogan, N.N. Poznyakovskaya, T.I. Goldfarb, and M.A. Gozenpud, violinists P.S. Stolyarsky, D.F. Oistrakh (occasionally), M.B. Rejson, and I.M. Yampolsky, cellist A.P. Stogorsky, musicologists L.A. Mazel, V.A. Zuckerman, M.S. Druskin, M.S. Pekelis, D.V. Zhitomirsky, E.S. Berlyand-Chyornaya, B.S. Shteinpress, Z.I. Gorodetskaya, A.M. Veprik, S.S. Bogatyrev, and K.R. Eiges, and folklorist L.L. Khristiansen. Undoubtedly, this consolidation had contributed to the formation of a high level of professionalism, building up the creative and scientific potential of the institution. At that time in the Urals, there were formed and fruitfully developed the traditions of different national musical talents performing, composing, and conducting scientific schools.

Such an influx of famous musicians even caused some problems with "employment", leading to the division of departments, introduction of new specialties and subjects, and partitioning of staffing positions. Sometimes it caused curious situations. For example, according to order № 327 dated 3 December 1941: "Acting Professor Gozenpud A.A. and Associate Professor Zhitomirsky are to be appointed as assistants of the music history class, with half-pay salary for each" [6].

It is very unlikely that any other national conservatoire could ever gather such a faculty of celebrities! It was a unique situation involving the collaboration of different creative schools; thus local and evacuated students could continue their education with the best musicians.

Amazing scientific conferences took place in the young institution during the war years; also, the first theses were presented. In 1943, a special 10-year music school, affiliated with Sverdlovsk Conservatoire, was opened. I.D. Glezer, a pianist from Kiev, became its director.

The $29^{\text {th }}$ June 1945 saw Decree No. 9972 by the USSR's Council of People's Commissars, which stated, "Sverdlovsk State Conservatoire named after M.P. Mussorgsky is to be renamed into the Ural State Conservatoire named after M.P. Mussorgsky" [7]. The Conservatoire was to be renamed due to its significance for the whole region.

\section{THE WAY TO MATURITY}

An indicator of the successful institutional development was the first victories of its students in Moscow competitions. 
Pianist U. Muravlyov received Third Prize in 1945 at the Third All-Union competition of performing musicians, while in 1946, in the Second All-Union competition of variety performers, Second Prize was won by a duet by Lyudmila Lyadova and Nina Panteleeva.

The Conservatoire also carried out important tasks of musical enlightenment. In 1945, it put on the specially affiliated establishment "Weekend musical university for the city students". The height of the Conservatoire's musical enlightenment came in the 1960s and especially 1970s, when it was organized by Vice-Rector for research N. A. Vol'per.

The Ural Conservatoire, with its unique place in the center of multinational Eurasia, has played an important part in the musical culture of the foundation of the Russian UralSiberian region. The Conservatoire's graduates work in many republics as well, often in managing positions. Yet, in 1940, Moscow saw a decade of Buryat-Mongol art - the first of a number of RSFSR's festivals of autonomous republics which was prepared with the help of the Sverdlovsk Conservatoire under the guidance of its director M.P. Frolov, author of the first Buryat opera "Enkhe-Bulat-Bator", and his disciples, Buryat composers B. Yampilov and D.D. Ayushev. The National section for Yakutia, Buryatia, and Bashkiria students was opened in the Conservatoire in 1944. Later, such an opportunity attracted foreign students - initially from Mongolia, then South Korea, China, Latin America, etc. [8].

While generally the Conservatoire's development was progressive, the post-war years brought significant losses. Their reason was a Decree of the Politbureau of the Central Committee of the All-Union Communist Party of the Bolsheviks dated $10^{\text {th }}$ February 1948 and the notorious fight between "formalism" and "cosmopolitism". These led to frequent changes of directors, closure of the Composition Department and disestablishment of the Musical Comedy Department, and the discharge of respected teachers (including the Conservatoire's director, musicologist N.F. Orlov, composer O.K. Eiges, conductor S.S. Bergolts, and stage director E.A. Brill). In the 1950s, the Ural region became the USSR's nuclear center, which doubled the existing "Iron Curtain" and cultural isolation; subsequently, some musicians left the region. Meanwhile, however, some metropolitan musicians came to the Urals, although not always by choice, truth be told. Among them were musicologist V.D. Konen, pianist M.I. Renzin, violinists N.A. Shvarts and L.M. Mirchin, and cellist G.D. Tsomyk.

The 1950-60s period was marked by a strong ascent of the choir culture and large-scale song festivals in the USSR. In the Middle Urals, it was led by the Conservatoire teachers L.L. Christiansen, V.A. Glagolev (conductor of the combined choirs on the song festivals), and G.P. Rogozhnikova, who had been chairing a Choir Society of the Sverdlovsk region for more than 20 years [9]. The most memorable event of those years was the performance of Sviridov's "Pathetic Oratorio" on Sverdlovsk main square by a giant choir and orchestra, conducted by the Conservatoire's Professor M.I. Paverman in May of 1963.

1963 was also marked by the birth of the Folk Instruments Department, headed by E.G. Blinov. This "breakthrough" from academic traditions was questioned by the professor's senior generation. But the Department turned out to be so viable that it soon took a leading position in the Conservatoire [10].

The 1970s saw a collaboration of the Musical Theatre Department and the Orchestra Conducting Department, led by M. Paverman, who had organized orchestras in the Conservatoire and Philarmonic society since the 1930s. Beginning in the $1950 \mathrm{~s}$, his students conducted the Conservatoire's Opera House's Musical Comedy Theatre's performances. In 1970s the most famous of them E.V. Kolobov (later, the creator of the "New Opera" in Moscow) - staged the students' performances (many in the original languages) in cooperation with Stage Director A.B. Titel. All their Conservatoire and Opera House performances saw full houses and great public response.

In 1984, the Ural Conservatoire was awarded the Order of the Red Banner of Labor for its great achievements and in connection with its $50^{\text {th }}$ Anniversary.

\section{TIME OF CHANGE}

In the perestroika (country reconstruction) period, when culture and education financing was significantly reduced, the quantity of staff was also cut and the profession lost its prestige to some extent. However, one cannot deny positive changes as well: In the post-Soviet period, people from the Urals finally acquired opportunities for travelling abroad; bilateral international relationships were developed and Conservatoire musicians gave master classes and received guests, performed on all continents, and successfully worked in a number of countries. An outstanding Armenian composer, Avet Terteryan, had full privileges to teach and create in the Conservatoire in 1990s.

In addition to those teachers previously mentioned, over the years, the Ural Conservatoire saw such teachers as M.G. Bogomaz, A.G. Fridlender, P.A. Nozdrovskaya, E.M. Orlova, O.A. Moravyov, N.M. Puzey, I.Z. Zetel, M.V. Andrianov, Y.H. Vutiras, I.M. Nesterov, A.Y. Trofimov, Z.I. Alyoshina, I.B. Blinova, V.V. Midyushko, V.T. Fedenko, Z.A. Vizel, V.A. Pal'mova, S.G. Pochekin, D.P. Petukhov, M.L. Muginstein, E.A. Rubakha and others. Among those still working presently are V.D. Shkarupa (Rector since 2010), M.G. Vladimirova, N.G. Pankova, N.Y. Atlas, V.V. Klishin, V.B. Zavadsky, S.G. Beloglazov, L.K. Shabalina, A.G. Korobova, M.V. Gorodilova, T. Kaluzhnikova, L.A. Serebryakova, A.K. Sidorov, V.P. Ivukin, G.S. Yarkova, M.A. Umansky, A.B. Byzov, and other excellent specialists.

Among the Conservatoire graduates, there are such famous musicians as singers B. Shtokolov, Y. Gulyaev, V. Bayeva, I. Semenov, D. Dashiev, T. Purevdorzh, N. Golyshev, S. Zaliznyak, V. Ognovenko, and E. Voznesenskaya, composers L. Lyadova, E. Rodygin, V. Bibergan, N. Morozov, and A. Pantykin, conductors P. Gorbunov, V. Utkin, E. Kolobov, E. Brazhnik, V. Gorelik, and D. Volosnikov, choirmasters G. Rogozhnikova, N. Mal'ginova, N. Groshikova, and N. Popovich, pianists S. Lidskaya, K. Korchinskaya, and G. Reznikov, stringed instrument players I. Kuznetsova, G. Terya, V. Usminsky, 
and S. Peshkov, folk instrument players V. Roman'ko, S. Amirov, T. Volskaya, and M. Ulyashkin, wind instrument players V. Volkov, V. Chekasin, and I. Parashchuk, musicologists E. Maiburova, V. Kostarev, and Z. Vizel, and many others. V.I. Kazenin, head of Russian composers' union 1990-2014, was a Conservatoire graduate. In 2012, People's Artists of Russia Kazenin and Bibergan became Honored Professors of the Conservatoire.

Currently, musical education in the Ural State Conservatoire named after M.P. Mussorgsky is offered in 16 departments, in the form of baccalaureate, specialization degree, master's degree, post-graduate course, and assistantship and internship programs.

Teachers and concertmasters are the pride of the Conservatoire. About $90 \%$ of the specialists hold academic degrees of Professors and Associate Professors, DSc and PhD in Art, or honorary titles of People's and Honored Artists, and Honored Workers of Arts.

Throughout its existence, the Ural Conservatoire has always influenced the cultural life of the city of Yekaterinburg, the region, and the state by offering concerts and enlightenment activities, formation of choirs, folk musical theatres, etc. In the Conservatoire, much attention has been given to the organizing of festivals of different types, musical competitions, and scientific-methodological conferences. Teachers regularly give master-classes and render creative or practical support to different musical establishments in the region.

The Conservatoire has provided all three grades of musical institutions with the skilled personnel around Yekaterinburg and in other regions (Perm, Chelyabinsk, Kurgan, Tyumen, Krasnoyarsk, Omsk, etc.). The Conservatoire graduates are the backbone of the symphony orchestra and choirs in Philarmonic Societies and musical theatres; they work in orchestras and Opera houses in Russia (including the Bolshoy Theatre, New Opera, NemirovichDanchenko theatres, "Gelikon-Opera" as well as the Mariinsky Theatre in St-Petersburg). They make tours abroad to the Metropolitan Opera, Grand Opera, and others. The Youth Symphony Orchestra at the Philarmonic and the municipal orchestra "BACH" mostly consists of Conservatoire students and graduates. Additionally, Conservatoire teachers and graduates successfully direct a large number of musical unions.

\section{CONCLUSION}

Currently, several creative teams exist at the Conservatoire: Students' Symphony Orchestra and Concert Symphony Orchestra (conductor A. Shaburov), Folk instruments Orchestra (conductor N. Karamysheva), Students' Choir (art director V. Zavadsky), Opera-Studio (art director P. Koblik), wind instruments orchestra (conductor Y. Buchukov), and the wood wind quintet "Astrum" (art director M. Shykov)

At the Conservatoire, serious research work is carried out, and the impressive outcome of it is in the form of fundamental monographies, collected articles, and the defenses of theses (candidate and doctoral). The conservatoire is a member of the United Dissertation Council and contributor to the specialized scientific journal "Musical Science", and is currently under review of the High Attestation Committee of the Russian federation.

Modern multimedia technologies have been adopted by the Conservatoire and this resulted in the formation of a sound acoustic studio, then of a sound producing department - the first such of all Russian conservatoires. Important creative events are held at the Conservatoire, such as regular international festivals and competitions of electroacoustic music, ">SYNC". The sound-producing studio and the department contribute to the name of the Conservatoire in becoming well-known in this sphere as achieving the highest standards.

The Conservatoire teachers and students produce largescale concert work not only in the Conservatoire but in the halls of Philharmonic societies, musical colleges, schools, children's homes, hospitals, and museums throughout the Ural Federal District. The Conservatoire regularly takes part in all cultural events held by the municipal administration and cultural center of Yekaterinburg diocese.

Opera studio annually stages several productions in Yekaterinburg, most of them debuted there. The following productions have been running for more than three years: Puccini's opera "Gianni Schicci", H. Purcell's "Dido and Eneas", and K. Orff's "Die Kluge"; they were all awarded the B. Pokrovsky Prize (the only conservatoire to receive this prize three years in a row). Among new performances which received a great reception are the following: "Pushkin Tchaikovsky" with its original concept, Eugene Onegin"Playing the Classics", K. Molchanov's "The Dawns Here Are Quiet" (dedicated to the $70^{\text {th }}$ Victory Anniversary), and finally, "The Barber of Seville". This operatic bestseller was revived by the Conservatoire's Opera Studio for the 200th Anniversary of the premiere of Rossini's masterpiece.

The Conservatoire's staff performance is highly valued by the regional government. More than 70 teachers, graduates, and even undergraduate students have received a Governor's Award for their outstanding achievements in the sphere of literature and art since it was created in 1996. Students and teachers successfully participate in various competitions and festivals. At least 100 people annually become laureates and receive diplomas from national and international competitions.

The Ural Conservatoire has adapted to the modern environment. It has its own web site, which is constantly updated and upgraded. Internet opportunities are continually reviewed and the Conservatoire promotes itself in social networks (Facebook, VKontakte). In recent years, the Ural Conservatoire has regularly taken part in the International industrial exhibition INNOPROM with its innovative projects in the sphere of Internet educational technologies.

Always however, the Conservatoire never forgets its "top priority", which is determined by its name's etymology (from Latin servare - save, preserve) and which is not so simple today. The current task is the conservation and 
preservation of the highest values of culture, namely, conservare et multiplicare, from the Latin proverb which means - to save and multiply.

\section{REFERENCES}

[1] L. Shabalina. From musical classes IRMO to musical college named after P.I. Tchaikovsky // First Ural musical college / compiling authors I.V. Vinkevich. N.N. Ivanchuk. E.E. Polotskaya. L.K. Shabalina; edited by L.K. Shabalina. Yekaterinburg: Publishing house Sokrat, 2012, pp. 8-55.

[2] 80 years of the Ural Conservatoire in events and facts / compiling authors L.K. Shabalina, E.E. Polotskaya, A.G. Korobova and B.B. Borodin; edited by A.G. Korobova. L.K. Shabalina. Yekaterinburg: Publishing house AMB. 2014, pp. 8-12

[3] Order \# 12 at the Sverdlovsk State Conservatoire dated 29 October 1934 (From the Archive of the Ural State Conservatoire named after M.P. Musorgsky).

[4] L.K. Shabalina. E.E. Polotskaya. G.G. Neygauz and his Ural disciples // Theory of music society Journal. 2016. Edition No. 4 (16), pp. 1835. [Taken online]: http://journal-otmroo.ru/sites/journalotmroo.ru/files/2016_4\%2816\%29_3_Polotskaya_Shabalina_Neuhau s_Urals.pdf

[5] 80 years of the Ural Conservatoire in events and facts. Op. cit., p. 11.

[6] Order \# 327 at the Sverdlovsk State Conservatoire dated 3 December 1941 (From the Archive of the Ural State Conservatoire named after M.P. Mussorgsky).

[7] 80 years of the Ural Conservatoire in events and facts. Op. cit., p. 14.

[8] Ural State Conservatoire named after M.P. Mussorgsky. 75 years of history / compiling editors E.N. Fedorovich. L.K. Shabalina. Yekaterinburg: Ural State Conservatoire named after M.P. Mussorgsky. 2009, pp. 22-23.

[9] A Word about Master. Galina Petrovna Rogozhnikova. Choir Conductor - pedagogue - public figure. Articles, memories, materials]. Compiled by. A. Litvina. Yekaterinburg: Ural State Conservatoire named after M.P. Musorgsky, 2017, p.140.

[10] I. Gareyeva, "Evgeniy Blinov". M.: Publishing house of the Charity fund named after M.A. Matrenin. 2015. 